\title{
IN HAJTSVERZEICHNIS
}

Vorwort . . . . . . . . . . . . . . . . . . . . . VII

Ibkürzungen . . . . . . . . . . . . . . . . . . . . . . VIII

Finleitung. . . . . . . . . . . . . . . . . . . . . . . 1

Zur Transkription . . . . . . . . . . . . . . . . . . . . . . . . . . . 4

Quellen . . . . . . . . . . . . . . . . . . 8

Übersicht über die ostj. 1)ialekte (mit Karte) . . . . . . . . . . . . . . . 9

ler Vokalismus der ersten Silbe . . . . . . . . . . . . . . . . . . . . . 11

leer Vokalismus der heutigen ostj. llialekte. . . . . . . . 11

Quantitiat der Vokale. . . . . . . . . . . . . . . . . 11

Qualität der Vokale . . . . . . . . . . . . . . . . . 15

Vördliche Dialektgruppe . . . . . . . . . . . . . . . . . . . . . . . 15

Südliche llialektgruppe . . . . . . . . . . . . . . . . . . . . . . . . 21

Östliche Dialektgruppe . . . . . . . . . . . . . . . . . . . . . . . . 26

Vokalwechsel in den heutigen ostj. Dialekten . . . . . . . . . . . . . . . 33

Vokalwechsel in den öst. Dialekten . . . . . . . . . . . . . . . . . . 33

Vokalwechsel in den west. I)ialekten . . . . . . . . . . . . . . . 142

(ieschichte des ostj. Vokalismus............. . . 18

Allgemeine Cbersicht und Vokalgeschichte der J)ialekte . . . . . . . . is

Vach-Vasjugan . . . . . . . . . . . . . . . . . . . . . . 48

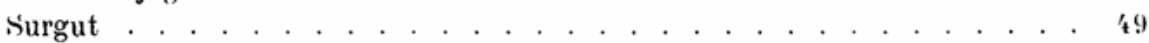

Obdorsk . . . . . . . . . . . . . . . . . . . 52

Irtysch . . . . . . . . . . . . . . . . . . . . . . . . . . . . . . . 53

Ni. Scher. Ber. . . . . . . . . . . . . . . . . . . . . . 53

Kazym . . . . . . . . . . . . . . . . . . . . . . 55

Geschichte der einzelnen urostj. Vokale . . . . . . . . . . . . . . 5

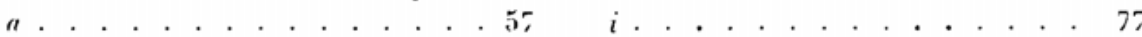

i............ . 60 i............ 78

๖. . . . . . . . . . . . . 60 $\ddot{u}$. . . . . . . . . . . . 79

j....................... 62 a 81

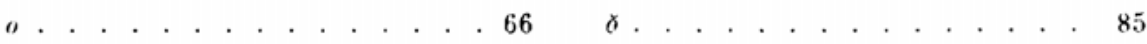

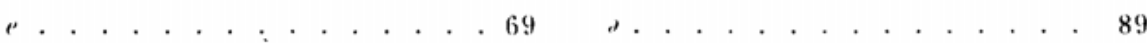

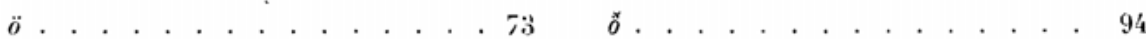

Tabellarische Öbersicht über die Vertretungen der urostj. Vokale. . . . 96

Geschichte des ostj. Vokalwechsels . . . . . . . . . . . . . . . . . . . . 98

Exkurs über die Wirkung von Palatovelaren auf benachbarte Vokale im Ostj. 111

Exkurs über urostj. ${ }^{*} \gamma$ und seine Beziehungen zum mrostj. Vokalismus . . . 116

Übergänge zwischen hinteren und vorderen Vokalen. . . . . . . . . . . . 130

Ostjakisches Wortregister . . . . . . . . . . . . . . . . . 131 
